\title{
Uso del almidón resistente a la amilasa más sales de rehidratación oral para tratamiento de la diarrea por cólera
}

Amylase-resistant starch plus oral rehydration solution for cholera. Ramakrishna BS, Venkatamaran S, Srinivasan S. N Engl J Med.2000; 342:308-313.

\section{Objetivo}

Evaluar la efectividad de las sales de rehidratación oral (SRO) más almidón resistente a la amilasa en el tratamiento de los pacientes con diarrea por cólera.

Diseño

Ensayo clínico randomizado.

Lugar

Christian Medical College and Hospital in Vellore, India.

\section{Pacientes}

Cuarenta y ocho pacientes adolescentes y adultos con edades comprendidasd entre los 14 y los 58 años con diarrea acuosa de menos de 72 horas de evolución y exámen microscópico de heces positivo para Vibrios.

Fueron excluidos los pacientes con enfermedades sistémicas severas o que hubieran recibido tratamiento antibiótico con anterioridad.

\section{Intervención}

Los pacientes fueron randomizados a recibir uno de tres esquemas de rehidratación: 1) sales de rehidratación estándar; 2) sales de rehidratación más $50 \mathrm{~g} / \mathrm{l}$ de harina de arroz; 3) sales de rehidratación más $50 \mathrm{~g} / \mathrm{l}$ de almidón resistente a la amilasa.

Cualquiera de las tres ramas de tratamiento se ajustó al plan propuesto por la Organización Mundial de la Salud (OMS) para deshidratación leve a moderada. Los pacientes con deshidratación severa se hidrataban por vía endovenosa primero y luego pasaban a la vía oral. Todos los pacientes recibieron la misma dieta y todos fueron tratados con $300 \mathrm{mg}$ de doxiciclina por vía oral luego de las primeras 24 horas de la admisión.

\section{Medición de resultados}

Los resultados principales fueron el peso de la materia fecal medido cada 12 horas en las primeras 48 horas posteriores a la inclusión y el tiempo transcurrido hasta que el paciente tuviera su primera deposición formada.

La ingesta y la excreción de líquido fueron medidas cada seis horas; mientras que los electrolitos, la uremia y la creatininemia fueron valorados diariamente.

\section{Resultados}

Como se muestra en la tabla 1, los pesos de la materia fecal fueron significativamente menores en los pacientes que habían recibido almidón resistente a la amilasa respecto de los asignados a la terapia convencional $(p=0.01)$.

\begin{tabular}{l|l|c|c|c}
\hline \multicolumn{2}{l|}{} & $\begin{array}{c}\text { Almidón resistente } \\
\text { a la amilasa }\end{array}$ & $\begin{array}{c}\text { Terapia } \\
\text { convencional }\end{array}$ & $\begin{array}{c}\text { Harina de } \\
\text { arroz }\end{array}$ \\
\hline \multicolumn{2}{c|}{ Duración de la diarrea\# } & $56.7 \pm 18.6 \mathrm{hs}$ & $90.9 \pm 29.8 \mathrm{hs}$ & $70.8 \pm 20.2 \mathrm{hs}$ \\
\hline $\begin{array}{l}\text { Peso de la } \\
\text { materia } \\
\text { fecal (12h) }\end{array}$ & $\begin{array}{l}12 \text { a } 24 \mathrm{~h} \\
\mathrm{p}=0.01\end{array}$ & $2206 \pm 1158 \mathrm{~g}$ & $3251 \pm 766 \mathrm{~g}$ & \\
\hline & $\begin{array}{l}24 \mathrm{a} 36 \mathrm{~h} \\
\mathrm{p}=0.04\end{array}$ & $1810 \pm 1018$ & $2621 \pm 1149$ & \\
\hline $\begin{array}{l}36 \text { a } 48 \mathrm{~h} \\
\mathrm{p}=0.01\end{array}$ & $985 \pm 668 \mathrm{~g}$ & $2498 \pm 1080$ & \\
\hline $\begin{array}{l}\text { depués de } \\
\text { las } 48 \mathrm{~h} \\
\mathrm{p}=0.01\end{array}$ & $985 \pm 668 \mathrm{~g}$ & & $1790 \pm 866 \mathrm{~g}$ \\
\hline
\end{tabular}

(\#) La duración de la diarrea fue menor en el grupo que recibió almidón resistente a la amilasa respecto del asignado a harina de arroz $(p=0.05)$ y a terapia convencional $(\mathrm{p}=0.001)$.

\section{Conclusiones}

La adición de almidón resistente a la amilasa a las SRO reduce la pérdida de líquido a través de la materia fecal y disminuye la duración de la diarrea en adolescentes y adultos con cólera.

\section{COMENTARIO}

Los autores del trabajo hipotetizan que el efecto beneficioso del almidón resistente a la amilasa estaría dado por su capacidad de pasar por el intestino delgado sin ser digerido llegando entonces al colon para ser metabolizado por las bacterias allí presentes y convertido en ácidos grasos de cadena corta. En el intestino grueso, estos ácidos grasos tendrían la capacidad de aumentar la absorción de agua y sodio además de proporcionar una fuente de enegía adicional. Si bien esta explicación es plausible, debemos tener en cuenta que el tratamiento más potente para reducir la duración de la diarrea en el cólera es la intervención antibiótica temprana. ${ }^{1}$ En el presente estudio la administración de antibióticos fue postergada por 24 horas, por lo tanto hace falta demostrar el beneficio adicional de la citada terapia comenzando en pacientes que reciben desde el inicio dicho tratamiento farmacológico. ${ }^{2}$ Además habría que valorar cual es la relevancia clínica de esta reducción en el peso y en la duración de los síntomas (ej. cuántos pacientes deshidratados en forma severa, internaciones, mortalidad, costos, ausentismo escolar/ laboral, etc.). Un aspecto que debemos tener en cuenta quienes trabajamos en Argentina es que en este trabajo se utilizó la solución de rehidratación estándar más el agregado de harina de arroz, mientras que en nuestro país, usualmente, dicha solución se prepara mezclando las sales con agua de arroz.

Es necesario contar con más evidencia que demuestre algún beneficio clínicamente relevante resultante de agregar o sustituir elementos de la terapia actual de rehidratación oral (el estándar universal de tratamiento) además del reconocidamente válido intento de mejorar la adherencia al tratamiento utilizando la estrategia de combinar la "verdad cintífica" con la "verdad folklórica".

Dr. Alfredo Gaete Unidad de Medicina Familiar y Preventiva. Hospital Italiano de Buenos Aires. 